\title{
Foreign bodies in the sigmoid colon of a psychiatric patient following self-mutilation: a case report
}

\author{
Hailu Wondimu Gebresellassie (D)
}

\begin{abstract}
Background: The act of deliberate injury to one's own body without the help of others is a well-known phenomenon in psychiatric patients. Insertion of foreign bodies into one or more orifices is not uncommon but insertion into a body cavity or the gastrointestinal tract by self-inflicted injury is quite rare.

Case presentation: A 32-year-old Ethiopian psychiatric patient presented with left lower abdominal pain of three months' duration following the insertion of foreign bodies via a self-inflicted wound in the left lower quadrant of his abdomen. Radiological evaluation demonstrated the presence of foreign bodies. A laparotomy revealed two metallic and three wooden materials in his sigmoid colon and a hole in his sigmoid that was tightly sealed with omentum. The foreign bodies were successfully removed, the hole was closed primarily, and our patient was discharged uneventfully.
\end{abstract}

Conclusions: This case illustrates that a foreign body can be inserted into the colon through a self-inflicted wound in psychiatric patients, and patients may present months later without having developed generalized peritonitis.

Keywords: Foreign bodies, Gastrointestinal, Laparotomy, Psychiatric, Patient, Self-inflicted, Case report

\section{Background}

Foreign bodies have been reported in various parts and levels of the gastrointestinal tract. Most commonly they are swallowed accidentally or intentionally, or introduced into the rectum for various purposes [1].

Insertion of foreign bodies as a deliberate act or form of self-injurious behavior is known to occur in psychiatric patients; these foreign bodies are often inserted into one or more orifices and are usually not fatal [2].

In this report, foreign bodies are described in the sigmoid colon of a 32-year-old psychiatric patient who inserted three wooden and two metallic materials through a self-inflicted wound in his left lower abdomen in a suicide attempt.

Correspondence: hailuwgs@gmail.com; hailu.wondimu@aau.edu.et; http://www.aau.edu.et/chs/academic-programs/school-of-medicine-and-tikuranbessa-specialized-hospital/surgery/staffs-of-surgical-department/ Department of Surgery, School of Medicine, College of Health Sciences, AAU, Addis Ababa, Ethiopia

(c) 2016 The Author(s). Open Access This article is distributed under the terms of the Creative Commons Attribution 4.0 International License (http://creativecommons.org/licenses/by/4.0/), which permits unrestricted use, distribution, and reproduction in any medium, provided you give appropriate credit to the original author(s) and the source, provide a link to the Creative Commons license, and indicate if changes were made. The Creative Commons Public Domain Dedication waiver (http://creativecommons.org/publicdomain/zero/1.0/) applies to the data made available in this article, unless otherwise stated.

\section{Case presentation}

I report the case of a 32-year-old Ethiopian male patient from Addis Ababa who presented with lower abdominal pain of three months' duration.

The abdominal pain started after our patient inserted metallic and wooden materials via a self-inflicted stab wound from a rusted knife into his left lower abdomen, 3 months prior to his presentation to our hospital. He stated that he did this to commit suicide. He did not seek any medical attention at that time because he had no family around and lived on the street. He claimed that he did not take any medication for the pain or the wound.

Our patient was taken to a clinic run by Missionaries of Charity in Addis Ababa by police after they saw the wound. He was then referred to our hospital for better management. Three months earlier, he had visited a psychiatric hospital for his psychiatric problems. He had not received any treatment because he had been asked to bring a relative with him to make sure he took his medications properly. He claimed that he occasionally used Khat (Khat is the fresh 


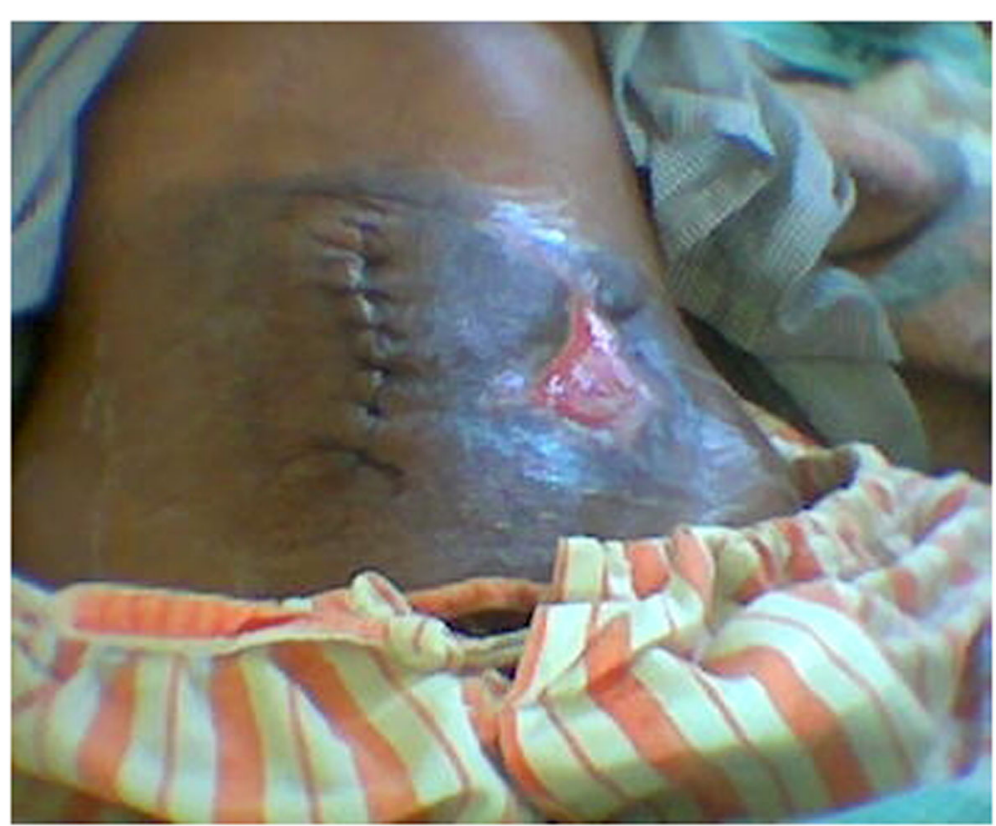

Fig. 1 Self-inflicted wound and midline laparotomy wound. Shows a healing wound with granulating tissue in the left lower abdomen with a skin defect and a lower abdominal midline surgical wound

leaves and twigs of the shrub Catha edulis, which has a stimulating and euphoric effect when chewed or brewed as tea). He was single and had completed 12th grade in school.

On examination, he was not sick looking, was indifferent to his surroundings, and had stable vital signs. The pertinent finding was of a clean, healing granulating wound in his left lower abdomen measuring $2 \times 2 \mathrm{~cm}$ with skin loss. There was tenderness on deep palpation in his lower abdomen but no rebound tenderness (Fig. 1).

Radiographic investigations revealed two radio-opaque shadows on the plain film of his abdomen, estimated to be $12-15 \mathrm{~cm}$ long (Fig. 2). We diagnosed intra-

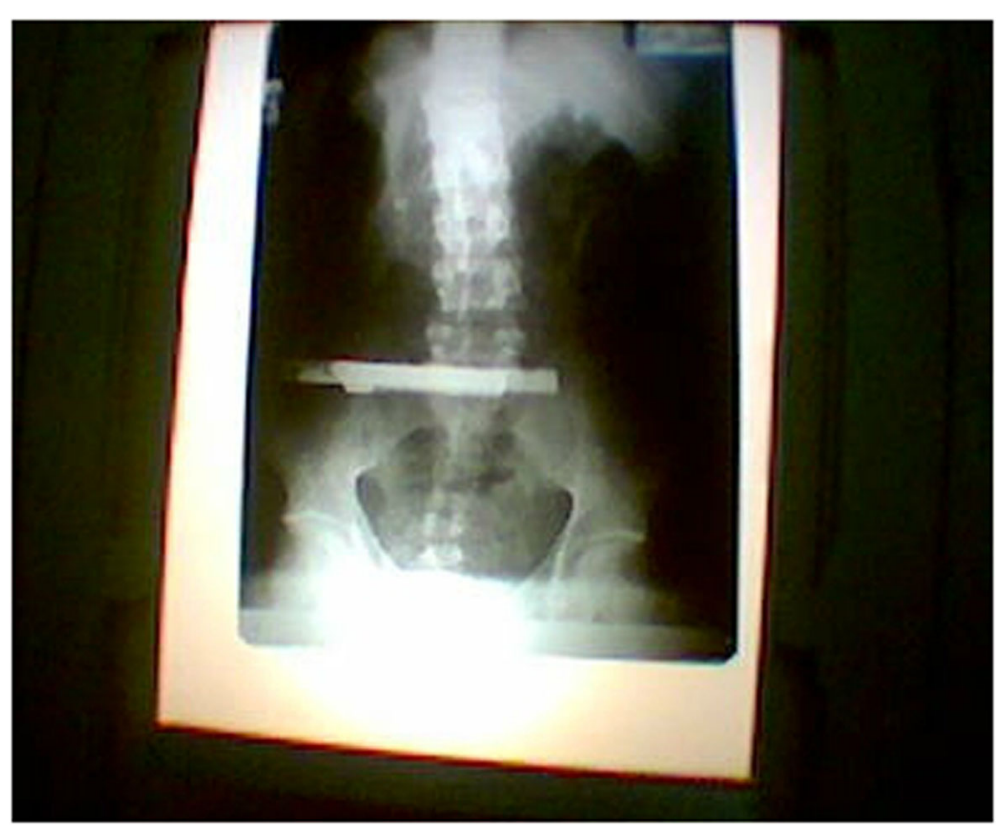

Fig. 2 Plain film of abdomen. X-ray shows radio-opaque materials lying transversely in the lower abdomen 
abdominal foreign bodies and opted for exploratory surgery.

A laparotomy revealed that the materials were lodged in his sigmoid colon. There were three wooden sticks of $8-10 \mathrm{~cm}$ in length in addition to two sharp pieces of saw (Fig. 3). The area including the perforation in the colon was completely sealed by omentum. The materials were extracted via an enterotomy on the antimesenteric side of his colon and the site was closed primarily. The area was lavaged with a liter of saline and his abdomen closed. Our patient had a psychiatric consultation and was started on appropriate medications. He was discharged a week later with no major complications.

Our patient was seen on two occasions after discharge and his surgical wound and stab wound healed completely. He started regular follow-up with the psychiatric unit of our hospital and showed marked improvement.

\section{Discussion}

Deliberate self-harm where individuals intentionally harm themselves is not uncommon in routine clinical practice but these injuries mostly do not threaten life [3]. This phenomenon typically occurs in young individuals with long-standing psychiatric problems [4]. Foreign bodies have been reported in the thorax, including the pericardium, and in various sites in the abdomen from self-inflicted wounds [5-7].

Evidence of self-mutilation and drug use have been reported in patients with severe psychiatric disorders and in incarcerated felons [8-10]. Therefore, self-mutilation should always be considered by emergency room physicians in cases of injuries in patients with unusual behavior and psychiatric disorders as well as incarcerated individuals $[11,12]$.

The fact that we found the foreign bodies partly lodged in the sigmoid colon of a patient who presented 3 months after the self-mutilation without having developing peritonitis is unusual. This case demonstrates that foreign bodies can enter the colon, via a selfinflicted wound as in our patient or accidentally, and the omentum can seal the area, thereby preventing the development of peritonitis.

Although foreign bodies can, as stated earlier, be found in any part of the gastrointestinal tract, they are not commonly described in the colon, as was found in our patient. Moreover, it is unlikely for any individual to inflict a wound on him or herself and introduce materials into the abdomen and not develop peritonitis, as in our patient. Our patient presented to a regular outpatient unit with no evidence of peritonitis although exploration revealed the materials to be in his sigmoid colon.

\section{Conclusions}

This case demonstrates that foreign bodies can enter the colon, via a self-inflicted wound as in our patient or accidentally, and the omentum can seal the area, thereby preventing the development of peritonitis.

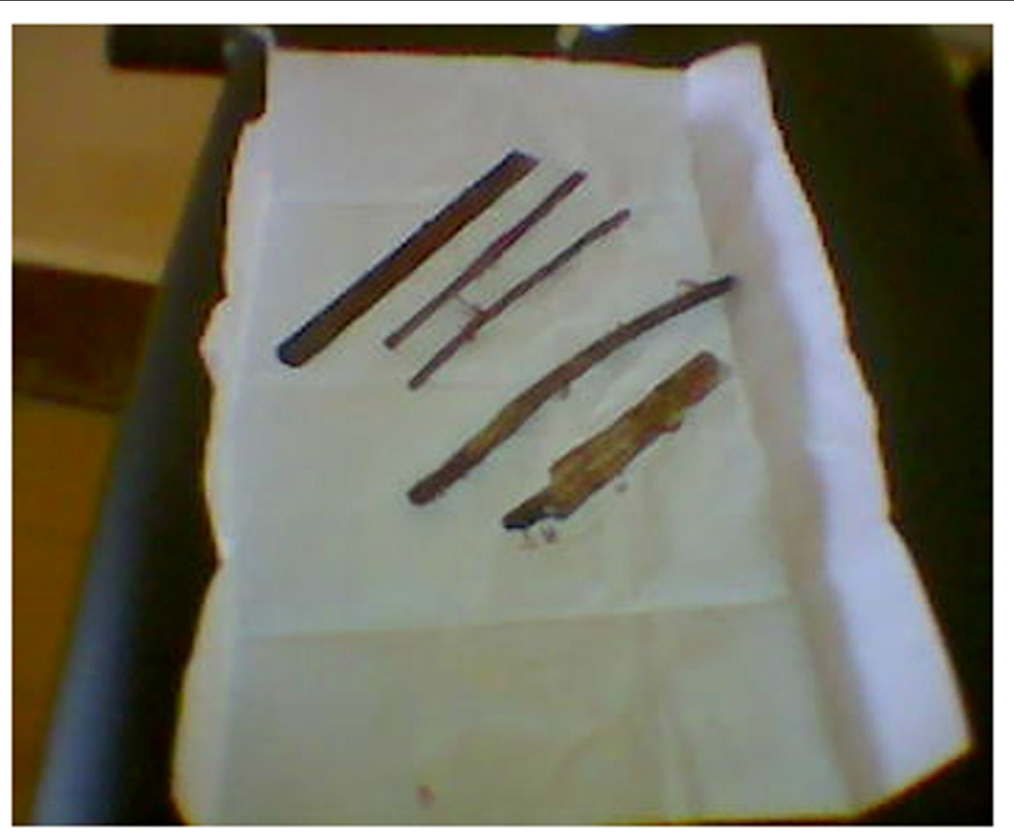

Fig. 3 Removed foreign bodies. The picture shows two metallic and three wooden materials removed during the laparotomy 


\section{Acknowledgements}

I would like to thank the staff in the surgical ward and operating theater of department of surgery as well as the psychiatric unit of the hospital.

\section{Funding}

No funding was used in the writing of the manuscript.

\section{Availability of data and materials}

There are no additional data and materials beyond those mentioned in the reference and within the manuscript.

\section{Authors' contributions}

HWG operated upon the patient and followed him in the post-operative period.

\section{Competing interests}

The author declares that he has no competing interests.

\section{Consent for publication}

Written informed consent was obtained from the patient once he was mentally capable and on follow-up by the psychiatrist for publication of this case report and accompanying images. A copy of the written consent is available for review by the Editor-in-Chief of this journal.

Received: 22 June 2016 Accepted: 26 August 2016

Published online: 17 September 2016

\section{References}

1. Ambe P, Weber SA, Schauer M, Knoefel WT. Swallowed foreign bodies in adults. Dtsch Arztebl Int. 2012;109:869-75.

2. Rao KN, Sudarshan CY, Begum S. Self injurious behavior: a clinical appraisal. Indian J Psychiatry. 2016;50(4):288-97.

3. Klonsky ED. The functions of deliberate self-injury: a review of the evidence. Clin Psychol Rev. 2007:27:226-39.

4. Unruh BT, Nejad SH, Stern TW, Stern TA. Insertion of foreign bodies (polyembolokoilamania): underpinnings and management strategies. Prim Care Companion CNS Disord. 2012;14(1):1-25.

5. Mujagić $\mathrm{S}$, et al. Foreign body in the urinary bladder of 14-year-old boy: case report and review of literature. Paediatrics Today [Internet]. 2015;1 1(1):54-8. doi:10.5457/p2005-114.110.

6. Bakal U, Tartar T, Kazez A. A rare mode of entry for needles observed in the abdomen of children: penetration. J Indian Assoc Pediatr Surg. 2012; 17(3):130-1.

7. Qian H, Song H, Li Y, Jiang C. Removal of metallic foreign body in heart by minimally invasive procedure under the guidance of transesophagea echocardiography and transthoracic echocardiogram. J Thorac Dis. 2015:7(11):560-3.

8. U.S. Prisons and Offenders with Mental IIIness Human Rights Watch New York Washington London Brussels [Internet]. 2003. 2-223. Available from: http://www.hrw.org

9. Baillargeon J, Penn JV, Thomas CR, Temple JR, Baillargeon G, Murray OJ. Psychiatric disorders and suicide in the nation's largest state prison system J Am Acad Psychiatry Law. 2009;37(2):188-93.

10. Nijman HLI, Dautzenberg M, Merckelbach HLGJ, Jung P, Wessel I, Campo J. Selfmutilating behaviour of psychiatric inpatients. Eur Psychiatry. 1999;14(1):4-10.

11. Grimes IC, Spier BJ, Swize LR, Lindstrom MJ, Pfau PR, Grimes IC, et al. Predictors of recurrent ingestion of gastrointestinal foreign bodies. Can $J$ Gastroenterol. 2013;27(1):1-4.

12. Royal $\mathrm{T}$, County $\mathrm{S}$. The surgical management of patients who deliberately self-harm. Ann R Coll Surg Engl. 2009;91(1):59-62.

\section{Submit your next manuscript to BioMed Central and we will help you at every step:}

- We accept pre-submission inquiries

- Our selector tool helps you to find the most relevant journal

- We provide round the clock customer support

- Convenient online submission

- Thorough peer review

- Inclusion in PubMed and all major indexing services

- Maximum visibility for your research

Submit your manuscript at www.biomedcentral.com/submit 